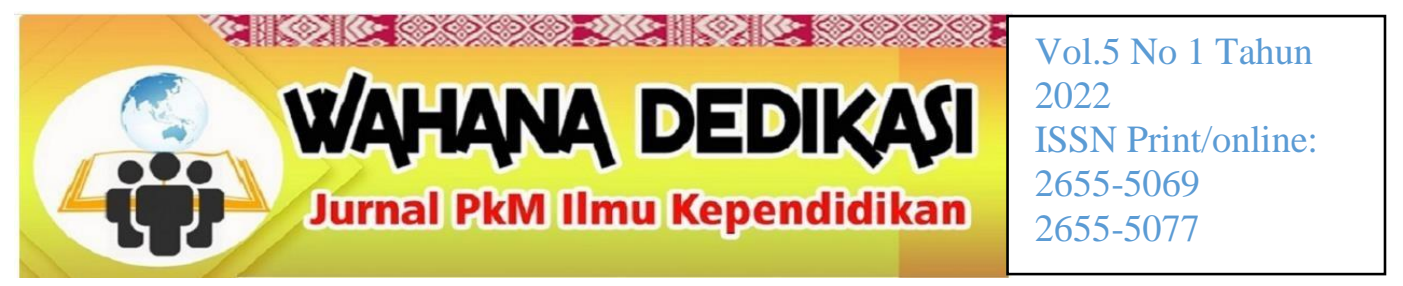

\title{
PENERAPAN PRINSIP PENDIDIKAN DALAM \\ PELAKSANAAN BIMBINGAN KONSELING DI ERA KENORMALAN BARU
}

\author{
Syska Purnama Sari ${ }^{1}$, Arizona ${ }^{2}$, Evia Darmawani ${ }^{3}$, Taty Fauzi ${ }^{4}$ Nurlela $^{5}$, \\ Endang Surtiyoni ${ }^{6}$, Ramtia Darma Putri ${ }^{7}$, M. Ferdiansyah ${ }^{8}$ \\ Program Studi Bimbingan dan Konseling Universitas PGRI Palembang \\ arizona.karno@gmail.com
}

\begin{abstract}
Abstrak
Pandemi covid 19 yang menciptakan kebijakan baru dari pemerintah yang berupa pembelajaran dari rumah. Pendidik dan peserta didik sebagai sasaran dari kebijakan tersebut harus mampu beradaptasi sehingga proses belajar mengajar berjalan dengan lancar. Tujuan kegiatan pengabdian adalah untuk memberikan pemahaman kepada peserta kegiatan yaitu guru-guru di SMK Negeri 1 Jejawi mengenai penerapan prinsip pendidikan dalam pelaksanaan bimbingan dan konseling di era kenormalan baru. Metode pelaksanaannya adalah ceramah atau seminar berupa sosialisasi, diskusi dan tanya jawab. Hasil kegiatan pengabdian didapatkan bahwa secara keseluruhan kegiatan yang telah dilaksana berjalan dengan lancar, dan kegiatan ini juga memberikan pemahaman kepada Guru-Guru mengenai pelaksanaan layanan BK yang dapat membantu peserta didik dan pendidik dalam proses belajar mengajar secara daring di era kenormalan baru.
\end{abstract}

Kata kunci: Prinsip Pendidikan, Bimbingan dan Konseling, Kenormalan Baru

\begin{abstract}
The Covid 19 pandemic which created a new policy from the government in the form of learning from home. Educators and students as the targets of this policy must be able to adapt so that the teaching and learning process runs smoothly. The purpose of the service activity is to provide understanding to the participants of the activity on the application of educational principles in the implementation of guidance and counseling in the new era of normality. The method of implementation is a seminar in the form of socialization and discussion. The results of the service activities found that overall activities have been carried out smoothly, and this activity also provides an understanding to teachers about the implementation of BK services that can help students and educators in the teaching and learning process boldly in the new normal.
\end{abstract}

Keywords: Principle of education, Guidance and counseling, new normal

Artikel Diterima : 19-01-2022 Artikel disetujui tanggal:28-01-2022 Artikel Diterbitkan :08-02-2022 Corresponden Author:Arizona e-mail:Arizona.karno@gmail.com

DOI: $\underline{\text { http://dx.doi.org/10.31851/dedikasi.v5i1. } 7261}$ d

\section{PENDAHULUAN}

Pandemi covid 19 yang sedang sangat meresahkan saat ini telah mempengaruhi berbagai sektor kehidupan masyarakat seluruh dunia, termasuk Indonseia. Tidak terlepas pengaruh tersebut terjadi dilingkungan pendidikan. Pandemi Covid 19 mengakibatkan banyaknya kebijakan-kebijakan baru yang dibuat oleh pemerintah, salah satu kebijakan yang dibuat adalah pelaksanaan kegiatan pembelajaran. Menurut Aryansah dan Sari Kebijakankebijakan yang dikeluarkan oleh pemerintah tersebut merupakan alternatif pilihan yang rasional dengan tujuan untuk mencegah 


\section{VAHANA DEDIKASI}

penyebaran virus 19 . Saat ini pandemi covid berada pada masa transisi dan telah memasuki masa perkenalan baru. Daerah berzona hijau dapat melakukan tatap muka pada tahun ajaran baru dengan tetap memperhatikan kesehatan dan keselamatan semua yang terlibat dalam pembelajaran tersebut. Namun sekolah-sekolah yang telah melaksanakan pembelajaran tatap muka masih sangat sedikit, khususnya di Provinsi Sumatera Selatan, awal tahun 2021 kemarin Gubernur Sumatera Selatan mngeluarkan surat edaran bahwa penundaan kegiatan pembelajaran tatap muka.

Proses pembelajaran daring
yang dilakukan saat ini
mengakibatkan Guru, siswa bahkan orang tua harus mampu beradaptasi dengan metode pembelajaran yang baru, sehingga berbagai permasalahan dialami, diantaranya kesiapan pendidik menerapkan prinsip pendidik memenuhi kebutuhan sesuai dengan kondisi yang ada di sekitar peserta didik. Karena dengan adanya wabah Covid 19 maka kegiatan pembelajaran yang seharusnya dilakukan tatap muka tidak dapat dilakukan secara tatap muka diubah menjadi pembelajaran online melalui berbagai aplikasi. Hal ini juga dialami dalam pelayanan bimbingan dan konseling, Guru BK juga dituntut untuk tetap memberikan layanan yang baik meskipun dalam kondisi serba sulit seperti ini. Guru BK memerlukan berbagai kordinasi dengan berbagai pihak sehingga terhindar dari pelanggaran kode etik bimbingan dan konseling demi kepentingan peserta didik. Rosadi dan
Andriyani mengungkapkan bahwa praktek pembelajaran secara daring dengan kurikulum merdeka belajar maka Guru BK sangat berperan penting untuk tidak memberikan materi saja tetapi juga diharapkan dapat memberikan pendidikan karakter sehingga akan berguna bagi peserta didik(Rosadi, Hesti Yulia \& Andriyani, 2020).

Di dalam proses pembelajaran daring di masa pandemi Covid 19, pendidik dan peserta didik dapat memanfaatkan kesempatan, waktu dan peluang agar lebih produktif dalam mengembangankan kemandirian terutama bagi peserta didik yang kritis, namun berbeda dengan peserta didik yang malas mengerjakan tugas semakin menumpuk tentu menjadikan hambatan bagi Pendidik, namun hal ini dapat menjadi peluang bagi pendidik untuk dapat menumbuhan pemahaman dan kesadaran agar dapat memiliki motivasi yang tinggi selama mengikuti proses belajar mengajar dan memproleh prestasi yang tinggi. Selain itu pendidik dan peserta didik dapat mengatur jadwal pembelajaran dan penyelesaian tugas secara feleksibel serta peluang bersama keluarga lebih banyak watunya (family time).

Kegiatan bimbingan dan konseling akan selalu terkait dengan pendidikan, karena keberadaan bimbingan dan konseling dalam pendidikan merupakan konsekuensi logis dari upaya pendidikan itu sendiri. Menurut Yusuf dan Nurihsan pendidikan yang hanya melaksanakan bidang administratif dan penagajaran dengan mengabaikan bidang 


\section{VAHANA DEDIKASI}

bimbingan mungkin hanya akan menghasilkan individu yang pintar dan terampil dalam aspek akademik, tetapi kurang mampu atau matang dalam aspek psikososiospiritual (Yusuf, Syamsu \& Nurihsan, 2005). Sehingga layanan bimbingan dan konseling akan menunjang keberhasilan pendidikan yang bermutu pada umumnya. Sesuai yang diungkapkan oleh Suherman bahwa bimbingan merupakan bagian dari program pendidikan yang diberikan secara individual dan sosial (Suherman, 2007).

Dengan kata lain, pendidikan dapat memanfaatkan bimbingan dan konseling sebagai mitra kerja dalam melaksanakan tugasnya secara fungsional. Bimbingan dan pendidikan sebagai proses interaksi, selalu berhadapan dengan kepribadian manusia yang sedang berkembang. Pendidikan bertugas membantu manusia mencapai tingkat perkembangan yang lebih tinggi, dan mewujudkan suasana belajar dan proses pembelajaran agar peserta didik secara aktif mengembangkan potensi dirinya untuk memiliki kekuatan spritual keagamaan, pengendalian diri, kepribadian, kecerdasan, ahlak mulia, serat keterampilan yang diperlukan dirinya, masyarkat, bangsa dan negara. Pendidikan merupakan proses yang bersifat individual sehingga strategi pendidikan harus dilengkapi dengan strategi khusus yang lebih intensif dan menyentuh dunia kehidupan secara individual. Menurut Kartadinata Strategi ini dapat memperhalus, menginternalisasi, dan mengintegrasikan sistem nilai dan pola prilaku yang dipelajari lewat proses pendidikan secara umum (Kartadinata, 2007).

Oleh karena itu tim Dosen Program Studi Bimbingan dan Konseling Universitas PGRI Palembang perlu memberikan kegiatan sosialisasi kepada Guru-guru di SMK Negeri 1 Jejawi OKI agar memahami dan mampu mengimplementasikan prinsip pendidikan di dalam penerapan bimbingan dan konseling di era kenormalan baru.

\section{BAHAN DAN METODE}

Metode yang digunakan dalam pengabdian kepada masyarakat ini metode ceramah atau seminar berupa sosialisasi, diskusi dan tanya jawab. Menurut Kustin dkk metode seminar adalah suatu kegiatan ilmiah yang dilaksanakan oleh beberapa orang dalam suatu sidang yang berusaha membahas/mengupas masalah-masalah atau hal-hal tertentu dalam rangka mencari jalan memecahkannya atau pedoman pelaksanaannya (Kustian et al., 2019). Lokasi pengabdian masyarakat ini adalah SMK N 1 Jejawi, Ogan Komering Ilir. Melihat dari permasalah yang ada di Era Kenormalan Baru kami menawarkan untuk memberikan solusi berupa sosialiasi tentang Penerapan Pelaksanaan Bimbingan Konseling kepada Guru di SMK N.1 Jejawi OKI guna meningkatkan kesadaran siswa akan pentingnya merencana dan menata pendidikan agar pada era kenormalan baru.

Setelah diberikan sosialisasi, tim kegaiatan PKM mengadakan 


\section{W/AHANA DEDIKASI}

evaluasi beruapa pembagian kuesioner yang dibagikan kepada peserta kegiatan untuk diisi, hasil dari evaluasi tersebut akan menjadi bahan pertimbangan tidak lanjut dari kegiatan PKM tersebut.

\section{HASIL DAN PEMBAHASAN}

Dari permasalahan tentang prinsip pendidikan dalam pelaksanaan Bimbingan dan Konseling berbasis perencaraan pembelajaran di Era Kenormalan Baru, maka dilakukan PkM dan M.oU dalam bentuk ceramah atau seminar serta sosialisasi di SMK N Jejawi Oki, yang Terletak di Jalan. Raya Lintas Jejawi- Palembang.

Peserta pengabdian kepada masyarakat ini adalah guru dan juga ada peserta didik SMK Negeri 1 Jejawi guna mendapatkan informasi mengenai pembelajaran di era kenormalan ini. SMK Negeri 1 Jejawi memfasilitasi dengan menyediakan peserta yakni guru dan peserta didik. Selain itu, mitra menyediakan fasilitasi berupa ruangan lengkap multimedia demi kelancaran kegiatan yang dilakukan.

Pada akhir kegiatan

pengabdian kepada masyarakat dan sosialisasi ini diberikan tes karir untuk peserta didik. Selanjutnya, terdapat sesi tanya jawab untuk melihat tercapainya pengetahuan apa yang didapatkan oleh peserta setelah mendapatkan materi pelaksanaan bimbingan dan konseling berbasis perencanaan pembelajaran di Era Kenormalan Baru ini. Dalam hal ini memberikan kesempatan kepada guru dan peserta didik untuk lebih lanjut berkomunikasi dan interaksi terkait dengan informasi kampus dalam lingkup pendiidkan karir di masa depan.

\section{Penerapan Prinsip Pendidikan dalam Bimbingan dan Konseling Menurut Kemendikbud (Sulkipani, 2014) ada lima prinsip pendidikan nasional adalah sebagai berikut :}

1. Prinsip demokratis berdasarkan HAM, artinya di dalam pendidikan hak dan kewajiban pendidik dan peserta didik harus benar-benar diperhatikan. Hal ini sesuai dengan prinsip bimbingan dan konseling bahwa bimbingan diberikan kepada semua peserta didik, tidak hanya peserta didik yang bermasalah saja karena pada dasarnya tujuan bimbingan adalah untuk mengembangkan potensi individu sehingga setiap peserta didik pasti mempunyai potensi, dan peran BK disini sangatlah penting yaitu untuk mengembangkan potensi yang dimiliki oleh siswa sehingga siswa dapat mencapai perkembangannya dengan optimal.

2. Prinsip proses pembudayaan dan pemberdayaan sepanjang hayat, artinya proses belajar di sekolah merupakan proses belajar pembudayaan. Misalnya untuk mencapai akademik siswa, untuk membudayakan sikap, pengetahuan, keterampilan dan tradisi yang sesuai dengan norma dan adat istiadat bangsa. Penerapan di dalam bimbingan dan konseling adalah fokus bimbingan dan konseling tidak hanya pada bidang akademik saja, namun ada empat jenis bidang bimbingan yaitu bimbingan akademik, pribadi 


\section{VAHANA DEDIKASI}

sosial, karir dan keluarga. Sehingga di dalam masing-msing bidang bimbingan tersebut, guru BK dapat berperan untuk memberikan bimbingan kepada siswa agar dapat menampilkan perilaku, berpikir, dan memiliki karakter sesuai dengan norma, adat istiadat dan budaya bangsa.

3. Prinsip sistemik, prinsip terbuka, prinsip multimakna dan prinsip legalitas, artinya pendidikan harus dilaksanakan dengan melibatkan semua personel pendidikan, dilaksanakan oleh semua warga negara, dilaksanakan untuk mengembangkan berbagai aspek kehidupan dan dilaksanakan sesuai dengan peraturan. Prinsip ini sesuai dengan asas-asas bimbingan dan konseling, yaitu menurut Yusuf dan Nurihsan bahwa keberhasilan bimbingan dan konseling ditentukan oleh diwujudkan asasasa berikut yaitu rahasia, sukarela, terbuka, kegiatan, mandiri, kini, dinamis, terpadu, harmonis, ahli, alih tangan kasus dan tut wuri handayani (Yusuf, Syamsu \& Nurihsan, 2005).

4. Prinsip ing ngarso sung tulodho, ing madyo mangun karso, tut wuri handayani. Hal ini sesuai sekali dengan prinsip tut wuri handayani dalam bimbingan dan konseling, menurut Witono asas tut wuri handayani adalah asas bimbingan dan konseling yang melaksanakan layanan bimbingan dan konseling secara keseluruhan sehingga di dalam proses bimbingan guru BK dapat menciptakan suasana yang mengayomi, memberikan keteladanan, rangsangan dan dorongan, serta kesempatan seluas-luasnya kepada seluruh siswa (Witono, 2020).

5. Prinsip memberdayakan masyarakat, artinya pendidikan tidak hanya menjadi tanggung jawab pemerintah, tetapi juga menjadi tanggung jawab bersama anggota masyarakat. Di dalam penerapannya pada bimbingan dan konseling bahwa bimbingan dan konseling dapat memanfaatkan sumber daya masyarakat. Menurut Yusuf dan Nurihsan bahwa sekolah dapat menjalin kerjasama dengan unsur-unsur masyarakat yang dipandang relevan dengan peningkatan mutu layanan bimbingan (Yusuf, Syamsu \& Nurihsan, 2005).

\section{Pelaksanaan Bimbingan dan Konseling di Era Kenormalan Baru Materi Bimbingan dan}

Konseling di Era Kenormalan Baru disampaikan kepada Guru BK SMK Negeri 1 Jejawi dengan harapan agar dapat memberikan informasi kepada

Guru BK di SMK N1 Jejawi dapat mengimplementasikannya kepada peserta didik. Bimbingan dan konseling mengemban tanggung jawab untuk membantu individu agar mampu menyesuaikan diri terhadap dinamika dan kehidupan sosial. Hakikat manusia dengan segenap dimensi kehidupan manusia yang perlu dikembangkan, yaitu dimensi spritual dan psikologis, sosioemosional, fisik, serta segenap tujuan dan tugas kehidupan menjadi landasan bagi konsepsi dan penyelenggaraan bimbingan dan konseling. Manusia adalah segala- 


\section{VAHANA DEDIKASI}

galanya bagi pelayanan bimbingan dan konseling. Ini berarti bahwa hakikat tujuan bimbingan dan konseling harus bertolak dari sistem nilai dan kehidupan yang menjadi rujukan manusia yang ada dalam sistem kehidupan tersebut.

Kebijakan yang dikeluarkan oleh pemerintah dalam dunia pendidikan mengakibatkan berbagai macam masalah. Hal ini dikarenakan model pembelajaran yang baru dilaksanakan, menurut Aryansah dan Sari Guru dan Dosen masih banyak yang belum bisa mengajar dengan menggunakan teknologi dan berbagai macam aplikasi, sehingga pendidik memerlukan penyesuaian diri dalam melakukan pembelajaran, namun pembelajaran tersebut tidak berjalan lancar (Aryansah \& Sari, 2021). Selain itu Putra dan Shofaria mengemukakan bahwa proses pembelajaran pada masa pandemi covid memiliki hambatan akses teknologi, aspek pendidik, diri pribadi, keluarga dan permasalahan psikologis lainnya (Putra \& Shofaria, 2020). Begitu pula dengan Guru Bimbingan dan Konseling, Guru BK juga memiliki tantangan di masa pandemi covid 19. Menurut Anugrahana pada masa pandemi covid 19, layanan bimbingan dan konseling bergantung dengan internet, Guru BK dituntut untuk agar dapat mendukung layanan bimbingan dan konseling (Anugrahana, 2020).

$$
\text { Menurut }
$$

Musdalifah pembelajaran daring juga menuntut peserta didik harus memiliki tanggung jawab mandiri dalam belajar, dapat mengontrol sikapnya dalam belajar, menyelesaikan tugas melalui daring dan mengoptimalkan gadget sebagai sumber belajar (Musdalifah, 2020). Untuk membantu peserta didik memenuhi tuntutan tersebut, peran bimbingan dan konseling sangat diperlukan sehingga peserta didik dapat optimal dalam mengikuti pembelajaran daring. Selain itu Guru BK Selain itu menurut Sari bahwa Guru BK atau konselor sebagai tenaga profesional harus dapat menjalankan peran dan fungsinya yaitu salah satunya adalah guru BK perlu tanggap serta kreatif dalam melakukan inovasi-inovasi agar dapat memberikan layanan konseling yang lebih optimal (Sari, 2020). Begitu pula dengan menghadapi masalah-masalah dari pembelajaran daring, sebagi guru BK yang merupakan mitra dari personel sekolah yang lain, harus dapat berinovasi agar permasalahan yang dialami dapat terselesaikan dengan baik, sehingga peserta didikpun dapat mengembangkan potensinya.

Berorientasi pemecahan masalah baik dalam tataran obyektif (dalam proses mempelajari) maupun dalam tataran normativ (dalam proses membawa). Orientasi masalah dalam tataran obyektif terfokus kepada persoalan apa dan mengapa individu berada dalam kondisi demikian, dan orientasi masalah pada tataran normativ terkait dengan bagaimana mengembangkan, mengubah, dan memperbaiki kondisi tersebut. Pelayanan bimbingan dan konseling harus didasarkan norma-norma yang berlaku, baik isinya, prosesnya, tekniknya, maupun instrumentasinya yang dipergunakannya. Pelayanan yang tidak normatif bukanlah 


\section{VAHANA DEDIKASI}

pelayanan bimbingan dan konseling. Bimbingan dan konseling yang dimaksud disini merupakan pelayanan bantuan yang berakar pada budaya kita, dan mempunyai landasan ilmiah psikologi dan pendidikan. Salah satu solusi yang dapat digunakan adalah layanan dasar dan perencanaan individu, bimbingan, kelas besar atau kecil dan kelompok (hampir semua aplikasi internet) dan secara individu atau interaksi pribadi. Sedangkan responsif (konseling) interaksi pribadi, chatting, telphone, dan email. Menurut Sari bentuk layanan dapat digunakan dalam pelaksanaan metode pembelajaran jarak jauh pada masa pandemi covid adalah Cyber Counseling yang telah menjadi salah satu bentuk layanan yang memanfaatkan perkembangan teknologi dan informasi yang berkembang saat ini (Sari, 2020). Menurut Prasetya Guru BK dapat mengoptimalkan peran konselor dengan memanfaatkan cyber counseling untuk mengembangkan informasi dan mengembangkan sumber daya teknologi (Prasetya, 2017). Selain itu menurut Musdalifah cyber counseling dapat meningkatkan motivasi peserta didik untuk semangat belajar dan tetap tinggal di rumah dengan mengembangkan life skill secara online (Musdalifah, 2020).

Pelaksanaan bimbingan dan konseling dilakukan harus memperhatikan keamanan dan pelanggaran kode etik. Menurut Putri etika pelaksanaan layanan bimbingan dan konseling amencakup hal-hal sebagai berikut : (1) pembahasan tentang informasi kelebihan dan kekurangan layanan bimbingan dan konseling daring (2) penggunaan teknologi (3) bentuk layanan yang tepat (4) akses terhadap aplikasi komputer (5) hukum dan aturanaturan penggunaan teknologi (6) halhal teknis (7) persetujuan dari konseli mengenai teknologi yang akan digunakan (8) situs yang digunakan dalam pelaksanaan bimbingan dan konseling daring (Putri, 2020). Etika pelasanaan bimbingan dan konseling harus benar-benar diperhatikan karena menurut Sari bahwa layanan bimbingan dan konseling tidak dilakukan dengan asal-asalan dan memaksakan diri menggunakan konsep pembelajaran jarak jauh apabila layanan tersebut hanya akan mendapatkan permasalahan baru sehingga Guru BK harus benar-benar paham mengenai fungsi layanan yang akan dilaksanakan (Sari, 2020).

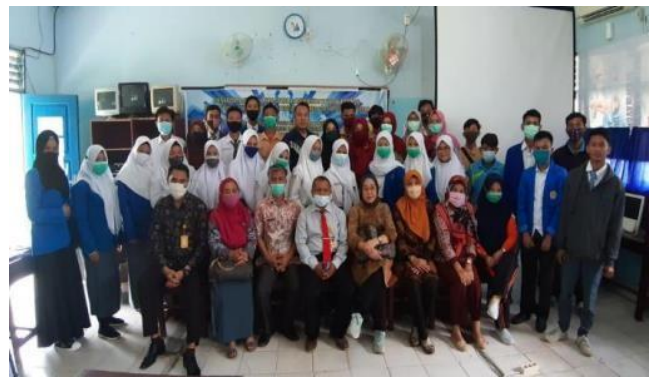

Gambar Foto Bersama dengan Kepala Sekolah dan Peserta Kegiatan

\section{KESIMPULAN}

Kesimpulan dari pengabdian kepada masyarakat yang telah dilaksanakan di SMK Negeri 1 Jejawi adalah sebagai berikut:

1. Secara keseluruhan kegiatan pengabdian kepada masyarakat berjalan dengan lancar.

2. Guru-guru sebagai peserta kegiatan sangat antusias dan 


\section{VAHANA DEDIKASI}

memberikan respon positif terhadap kegiatan pengabdian kepada masyarakat yang berjudul penerapan prinsip pendidikan dalam pelaksanaan bimbingan konseling berbasis perencanaan di Era Kenormalan Baru, selama kegiatan peserta kegiatan sangat interaktif.

3. Kegiatan pengabdian kepada masyarakat memberikan pemahaman kepada Guru-Guru khususnya Guru BK mengenai pelaksanaan layanan BK yang dapat membantu peserta didik dan pendidik dalam proses belajar mengajar secara daring.

\section{DAFTAR PUSTAKA}

Anugrahana, A. (2020).

Hambatan, Solusi dan Harapan:

Pembelajaran Daring Selama

Masa Pandemi Covid-19 Oleh

Guru Sekolah Dasar. Scholaria:

Jurnal Pendidikan Dan

Kebudayaan, 10(3), 282-289.

https://doi.org/10.24246/j.js.202

0.v10.i3.p282-289

Aryansah, J. E., \& Sari, S. P. (2021).

Analisis Peran Regulasi Emosi

Mahasiswa terhadap Kebijakan

School From Home Di Masa

Pandemi Covid 19. Jurnal

Pemerintahan Dan Politik, 6(1), 8-14.

Kartadinata, S. (2007). Teori Bimbingan Dan Konseling. Seri Landasan Dan Teori Bimbingan Dan Konseling, 10(1), 1-14. http://file.upi.edu/Direktori/FIP/J UR._PSIKOLOGI_PEND_DAN _BIMBINGAN/1950032119741 21-
SUNARYO_KARTADINATA/ TEORI_BIMBINGAN_DAN_K ONSELING-2.pdf

Kustian, N., Hidayatullah, R. S., \& Ridwan, R. (2019). Sosialisasi Pemanfaatan Aplikasi Sparkol Videoscribe dalam Pembuatan Bahan Presentasi pada Karang Taruna. Jurnal PkM Pengabdian Kepada Masyarakat, 2(01), 38. https://doi.org/10.30998/jurnalpk m.v2i01.2987

Musdalifah, A. (2020). MEDIA LAYANAN BIMBINGAN DAN KONSELING DI TENGAH PANDEMI COVID-

19. Prosiding Seminar \& Lokakarya Nasional Bimbingan Dan Konseling, 59-64.

Prasetya, A. F. (2017). Model Cybercounseling ChatAsynchonous : Upaya Konselor Meningkatkan Layanan Konseling Pada Siswa Sekolah Menengah Kejuruan (SMK). Prosiding Seminar Nasional: Peran Bimbingan Dan Konseling Dalam Penguatan Pendidikan Karakter, 326-332.

Putra, M. A., \& Shofaria, N. (2020). Inovasi Layanan Bimbingan Dan Konseling Di Masa Pembelajaran Dalam Jaringan Masa Pandemi Covid-19. Bikotetik (Bimbingan Dan Konseling: Teori Dan Praktik), 4(2), 55. https://doi.org/10.26740/bikoteti k.v4n2.p55-61

Putri, V. D. (2020). Layanan Bimbingan dan Konseling Daring Selama Masa Pandemi COVID-19. Jurnal Bimbingan Konseling Pendidikan Islam, 


\section{WAHANA DEDIKASI} 1(2), 7-16.

Rosadi, Hesti Yulia \& Andriyani, D. F. (2020). Tantangan Menjadi Guru BK dengan Kurikulum Merdeka Belajar di Masa Pandemi Covid 19. Prosiding Konfrensi Ilmiah Mahasiswa Unissula (KIMU)4, 356-363.

Sari, G. A. (2020). Guru Bimbingan Konseling dalam Fungsi pada Kegiatan Pembelajaran Jarak Jauh dari Rumah. Journal IKA: Ikatan Alumni PGSD UNARS, 8(2), 453-461.

Suherman, U. (2007). Manajemen Bimbingan dan Konseling (Jakarta). Madani Production.

Sulkipani. (2014). Prinsip-Prinsip dan Praktik Pendidikan untuk Membangun Warga Negara yang Demokratis. Jurnal Bhinneka Tunggal Ika, 100-107.

Witono, A. H. (2020). Peran Bimbingan dan Konseling dalam Penyelenggaraan Pendidikan Inklusif. Progres Pendidikan, 1(3), 154-167.

Yusuf, Syamsu \& Nurihsan, A. J. (2005). Landasan Bimbingan dan Konseling. Program Pasca Sarjana Universitas Pendidikan Indonesia dengan PT Remaja Rosdakarya. 